\title{
The Role of NGOs in Canada and the USA in the Transformation of the Socio-Cultural Structures in Africa
}

\author{
Charles Quist-Adade \\ \& Anita van Wyk*
}

\begin{abstract}
This paper aims to explain how International Non-Governmental Organisations (INGOs) in Canada and the United States of America assist in maintaining the West's hegemonic position in ongoing globalisation process, with specific reference to Africa. The process begins at the local community level with ordinary citizens in North America. These people are exposed to 'development pornography' through a plethora of visual, text and audio input via the mass media and popular culture, which present the African lifeworld as inferior and primitive, and African people as helpless, hapless, and in the throes of an unending series of epidemics on the short road to extinction. African cultures are portrayed as backward, atavistic, stuck in their primeval past, and needing 'modernisation' from the West. This African lifeworld is used to describe and portray Africa in ways that justify the importance of civil society organisations (CSOs) - charities, aid workers, business people, missionaries and non-governmental organisations (NGOs) - in 'intervening' in the African continent's seemingly inexorable human crises. INGOs, in turn, use this image as 'compassion usury', tugging on the heartstrings of North Americans to donate generously to various projects in Africa. Large amounts of money, goods and time are donated by ordinary people to help re-make the so-called inferior traditional lifeworlds of Africans in accordance with Western visions. In return, these donors receive generous rewards for their contributions, in the form of tax deductions, community recog-
\end{abstract}

* Kwantlen University College and University College of the Fraser Valley, British Columbia, Canada respectively. 
nition, and development fund awards. Many of these donors are so motivated that they become development tourists who regularly visit Africa, bringing back 'mercy-soliciting' images to raise funds and create jobs for NGOs. Horrific pictures further reinforce negative stereotypes and misconceptions about Africa. In this way CSOs, particularly those recognised in Canada and the USA as international NGOs, not only unwittingly export and impose North American values on Africans, but also serve and maintain the global status quo of Western hegemony and African dependence.

\section{Résumé}

L’objectif de l'étude est d'expliquer comment les Organisations non gouvernementales internationales (ONGI) canadiennes et américaines aident l'Occident à maintenir son hégémonie dans le processus de globalisation en cours, surtout en ce qui concerne l'Afrique. C'est un processus commence au niveau de la communauté locale avec les citoyens ordinaires de l'Amérique du Nord. Ces individus sont exposés à une " pornographie du développement » à travers une pléthore d'informations visuelles, écrites et audio par les biais des moyens de communication de masse et de la culture populaire. L’Afrique est par conséquent présentée comme étant un monde inférieur et primitif. Les Africains y sont également perçus comme étant des gens sans défense, malheureux, et en proie à une série interminable d'épidémies empruntant le court chemin de l'extinction. Les cultures africaines sont présentées comme arriérées, ataviques, enlisées dans leur passé primitif, et qui ont besoin d'une « modernisation » en provenance de l'Occident. Cette image de l'Afrique est utilisée pour la décrire de façon à pouvoir justifier le rôle des Organisations de la société civile (OSC), organisations caritatives, travailleurs humanitaires, hommes d'affaires, missionnaires et Organisations non gouvernementales (ONG), et leur intervention dans les crises humanitaires, en apparence inexorables, qui surviennent sur le continent africain. En revanche, les ONGI utilisent cet image comme moyen de « chantage compassionnel », tirant sur les cordes sensibles des Nord Américains en vue de les amener à faire généreusement des dons à divers projets en Afrique. Beaucoup d'argent, de matériels et de temps sont offerts par des citoyens ordinaires dans le but de refaire le supposé monde inférieur et traditionnel des Africains conformément aux visions de l'Occident. En contrepartie, ces donateurs sont récompensés de leurs contributions sous forme d'allègement fiscal, de reconnaissance pour services rendus à la communauté et de prix de fonds de développement. La plupart d'entre eux sont si motivés qu'ils deviennent des touristes de développement faisant le tour de l'Afrique et ramenant avec eux des images de « mendiants de pitié » dans le but de collecter des fonds et créer des emplois en faveur des ONG. Ces horribles images renforcent davantage les préjugés et autres idées fausses que les Occidentaux se font de l'Afrique. En agissant de la sorte, les OSC, particulièrement celles qui sont reconnues au Canada et aux États-Unis comme Organisations non gouvernementales internationales exportent à leur insu les valeurs nord- 
américaines et les imposent aux Africains. Ces dernières servent et maintiennent ainsi le statut quo global de l’hégémonie occidentale et de la dépendance africaine.

\section{Introduction}

You have seen it over and over again: Naked, emaciated children with protruding eyes, flies feasting in the gaping mouths; frail, half-clad, barefoot mothers barely able to look after their dying children. And a Westerner, wellfed, rosy cheeked, well-dressed and apparently driven by compassion, helping out the poor African victims of one of Africa's many scourges - AIDS, famine or drought. 'Development pornography' has become a potent 'compassion' tool in a hegemonic game in which North American non-governmental organisations are increasingly becoming the key players. African scholars have long recognised these disparaging and insulting images presented by the North American media and international NGOs. They know the monotonous old story, starting with the same one-dimensional character, set to a worn-out script. The story is one of failure, chaos, inadequacy and barbarism. The character is dependent and inferior. The script requires a North American voice evoking compassion, amusement or outrage in his ever-sosuperior listener or viewer (Quist-Adade 2001).

There is a treasure trove of history behind this. David Livingstone's 3Cs (Christianity, Commerce and Civilisation); the 'mission civilisatrice', or the Frenchmen's alleged duty to bring civilisation to the backward peoples; Kipling's 'White Man’s burden'; a phalanx of explorers, Christian missionaries, scientists, scholars, journalists and politicians - all created the image of a 'Dark Continent' populated by ignoble savages, bestial, cannibalistic, apelike quasi-humans. These were the 'fallen brethren' and it was the white man's heavy responsibility to save the heathenish Africans through civilising missions. Thus, 'the African' was presented as in need of salvation. The purpose of the original story was to prepare the minds of the Western public, and indeed Africans themselves, for the slave trade, for colonisation, and for the partition of Africa.

What you see today in the North American media and NGO 'development pornography' videos about Africa is the continuation of tradition, of an old habit, an old wine in a new bottle. Today, Africans and their continent are interpreted through the self-same colour-coded and colour-sensitive eyes of North American reporters and development tourists. Although North American sources have revised and fine-tuned the colonial narrative over the years, they have maintained the subtext of the original 'African story' as told by the early explorers, colonial masters and missionaries. While they avoid the blatancy of the past, they have introduced euphemisms. Thus, instead of 'primi- 
tive' or 'uncivilised', Africans are 'underdeveloped' or 'developing'. But the message is the same: the civilised and developed must bear the burden of civilising or developing Africa.

Development pornography has been defined as a kind of perverse enjoyment people get out of looking at other people's suffering (Gidley 2005). It is epitomised in this graphic description by Sankore (2006): 'An iconic poster example of these images is one of a skeletal two- or three-year-old brownskinned girl in a dirty torn dress, too weak to chase off flies settling on her wasted and diseased body and her big round eyes pleading for help. "A pound means a lot to her"; "a dollar can mean a difference between life and death"; "give something today" are generic riders' (p. 36).

The current preoccupation of North American media and international NGOs with 'development pornography'has several motives, all aimed at reinforcing the West's hegemonic position vis-à-vis Africa: (i) to drive home the message that Africans cannot govern themselves, that the continent 'is still stuck in its primitive, bloodthirsty past', that African nations squandered their 'golden opportunity' to build civilised states after they attained political independence (Nkrumah 1973:17); and (ii) to demonstrate the salvation inherent in Western cultural superiority.

Kwame Nkrumah (1973:4) offers a penetrating analysis of the joint role civil society and governments in the West play in maintaining the lop-sided global status quo. He observes that when, after centuries of exploitation, the colonial masters were forced to grant political independence to African countries, the masters were unwilling to cut the umbilical cords. To ensure that the old relationships remained intact, they propagated the myth (with the help of the mass media) of an affluent capitalist world promising abundance and prosperity for all. The aim, however, was the establishment within former colonies of a 'welfare state as the only safeguard against the threat of Communism'.

The mass media participate in the propaganda war. New technology like satellite television stations contributed towards massive brainwashing. This war of words and images is supplemented by written propaganda, embassy bulletins, and newspapers distributed by so-called independent and liberal publishers. 'The war of words penetrates into every town and village, and into the remotest parts of the "bush". It spreads in the form of freely distributed propaganda films praising the qualities of Western civilization and culture' (Nkrumah 1973:17).

Hegemony thus saturates the ex-colonies to such an extent that it shapes the reality of social experience. In this way, Boggs (1976) asserts, people contribute to the continued dominance of the ruling class, by accepting the 
dominant culture's values and assumptions as their own; repression is replaced by inculcation. As Boggs (1976:39-40) notes:

Where hegemony appeared as a strong force, it fulfilled a role that guns and tanks could never perform. It mystified power relations, public issues, and events; it encouraged a sense of fatalism and passivity towards political action; and it justified every type of system-serving sacrifice and deprivation. In short, it worked in many ways to induce the oppressed to accept or consent to their own exploitation and misery.

Thus, hegemony over truth and knowledge ultimately replaces troops and guns as the relevant tool of re-colonisation. In this way the 'psychological terrain' is prepared and the whole continent 'is besieged without a single marine in sight' (Nkrumah 1973:17). According to Nkrumah, 'the most pernicious aspect of this psychological warfare' is the campaign to convince Africans and the Western public that Africans cannot govern themselves, that they are unworthy of real independence, and that foreign rule is the only cure for their wild, war-like and primitive way of life (p.17). Nkrumah contends that 'imperialism has done its utmost to brainwash Africans into thinking that they need the straightjacket of colonialism if they are to be saved from their retrogressive instincts' (p.17).

Nkrumah (1973) adds that such was the age-old racist justification for the economic exploitation of the continent. The post-independence coups many of which were engineered by the United States government and some of its allies (Stockwell 1984) - and their concomitant cycle of crises termed as the coup-drought-famine syndrome are being used to corroborate 'imperialism's pet theory that Africans have shamelessly squandered the "golden opportunities" of independence, and that they have plunged their political kingdoms into blood and barbarism' (Nkrumah 1973:17). 'Therefore', he continues, 'the imperialist mission: we must save them anew; the press, films and radio are fast spreading the myth of post-independence violence and chaos. Everywhere, the more or less covert implication is: Africa needs to be re-colonized' (p.17).

\section{Globalisation, hegemony and North American INGOs}

This paper focuses on how Canada and the USA, with the assistance of international NGOs (INGOs ${ }^{1}$ ), maintain a hegemonic position in the ongoing globalisation process in Africa.

But before we begin our analysis of the role INGOs play in establishing and maintaining the global hegemonic positions, we need to define the terms 'NGO' and 'globalisation'. The label 'non-governmental organisation' is used to describe a wide variety of organisations, variously known as 'private 
voluntary organisations', 'civil society organisations' and 'nonprofit organisations' (Johnstone and McGann 2006:2). As Johnstone and McGann point out, the proliferation of international NGOs during the past two decades, as well as the growth in public and private grants and contracts flowing to these organisations, has enabled them to become powerful players in globalisation and world politics.

'Globalisation' is an umbrella term for a complex series of economic, social, technological, and political changes widely viewed as increasing interdependence and interaction between people and companies in disparate locations (Wikipedia 2006). The term is employed to describe the increased mobility of goods, services, labour, technology and capital throughout the world. Although globalisation is not a novel development, its pace has increased (especially since the 1980s) thanks to the advent of new technologies, especially in the area of digital communications.

The Global Policy Forum (2006:1) notes that 'many politicians, academics, and journalists treat these trends as both inevitable and (on the whole) welcome. But for billions of the world's people, business-driven globalization means uprooting old ways of life and threatening livelihoods and cultures. The global social justice movement, itself a product of globalization, proposes an alternative path, more responsive to public needs'.

Those who take a more cynical view and point to the vulnerabilities of the concept see globalisation as nothing more than an ideology and practice of corporate expansion across borders and a structure of cross-border facilities and economic linkages, which focus on the imperialistic ambitions of nations, corporations, organisations and their desire to impose themselves on various geographic areas (Ritzer 2003).

The ability of capitalist societies to adapt to change, while retaining their essential organisation and functioning, provides a lucid lesson in the workings of the post-Cold War international system. The concept of hegemony helps to understand this lesson. Simply put, hegemony is a 'style of state politics that preserves control by a leading group on the one hand while instituting economic, social, political and ideological changes on the other' (Muchie and Xing 2006:1). The concept hinges on the premise that the ruling elite 'maintain a certain degree of consensual hegemony by neutralizing the pressures of various contending forces that might otherwise trigger profound structural transformations' (Ibid.). Hegemony is therefore an expression of broadly based consent, manifested in the acceptance of ideas, and supported by material resources and institutions.

The aim and consequence of the hegemonic process is to defuse or neutralise existing and potential threats to the system without inducing a political 
revolution that could threaten the dominance of the power elite and the modus operandi of the system (Ibid.).

The Gramscian notion of hegemony also provides useful insight into the role civil society organisations - religious, labour, cultural, social and political groups, as well as informal educators - play in the unfolding post-Cold War globalisation system. The central premise of the hegemony theory hinges on the crucial inter-relationship of the state, civil society and economics in the maintenance of a given social formation (Ferguson 1998). The theory posits the use of coercion and consent to maintain power and the status quo, as well as the role of traditional and organic intellectuals and of mass participation in building counter-hegemony. According to hegemony theory, social reality is influenced by the ruling elite - cultural, ideological, political, military and economic - and functions to create consent within the public: between the ruling elite and the ruled, between government and civil society.

Hegemony presupposes counter-hegemony, a nexus of enlightened coercion by the ruling elite and passive consent from the ruled. This give-andtake strategy is made possible via an intricate system of socialisation, subtle manipulation and indoctrination of the ruled. For hegemony to be successful, it must be subtle, flexible and adaptable. In other words, the ruling elite must be dynamically responsive to the 'voices' of the ruled in order to have the popular support and legitimacy to maintain stability and power. This also means that the ruling elite must continuously negotiate its legitimacy, must be receptive to the voices of dissent and grievance of the disaffected 'masses', and must remove or neutralise points of contention.

Unlike the classical Marxist view of absolute control of ideological and cultural discourse by the dominant capitalist class, the neo-Marxist hegemony theory as postulated by Italian neo-Marxist Antonio Gramsci (1971) advances a more flexible, fluid and ongoing dynamic between super-ordinate and subordinate groups, between the rulers and the ruled. The hegemony/counterhegemony nexus involves resistance and incorporation, coercion and consent; enlightened coercion by the ruling elite and consent from the ruled. In other words, the power elite do not simply force their ideas onto the people, but shape and win consent so that the power of the dominant classes appears both legitimate and natural (Dyson 2003). However, at the same time some individuals and groups oppose these dominant ideas, refusing to conform to the norm. In the end, though, the ruling elite wins out and dictates the ideological and political direction of society. They do so very successfully by being flexible, adaptable and responsive to the moods of the changing times and sometimes to the temperament of ruled. For it is through such 
flexibility and adaptability that the ruling elite acquire the impetus and 'oxygen' needed to maintain its legitimacy (Quist-Adade 2001).

Thus, hegemony, according to Boggs (1976:39) is an 'organising principle' that is diffused by the process of socialisation into every sphere of daily life. 'To the extent that this prevailing consciousness is internalized by the population it becomes part of what is generally called "common sense" that the philosophy, culture, and morality of the ruling elite comes to appear as the natural order of things.'

Put another way, the process of hegemony allows the interests of the power elite to be universalised and naturalised as the interests of the society as a whole. The process of universalising and naturalising, according to Gramsci (1971), is accomplished on behalf of the power elite by 'organic intellectuals'2 who are distinguished by their ability to 'manufacture societal consent' about the moral compass of society and to shape and control the moral and intellectual life of society. Gramsci assigns a central role in the entire hegemony process to the 'collective organic intellectuals' who both actively and passively direct, shape and reform the cultural 'project' of society. According to Cahill (2000), organic intellectuals are organisers of hegemony who provide ideological leadership to a given class as well as articulating and implementing the hegemonic project of that class through the apparatuses of the state and the public sphere. Zygmunt Bauman (1992:1) describes organic intellectuals as:

those intellectuals who articulated the worldview, interests, intentions and historically determined potential of a particular class; who elaborated the values which needed to be promoted for such a potential to be fully developed; and who legitimised the historical role of a given class, its claim to power and to the management of the social process in terms of those values.

Hegemony manifests itself especially powerfully in the clash of global cultures.As purveyors of North American culture, the media, civil society organisations, and collective organic intellectuals, 'conspire' to impose their values and cultural norms on African societies through all manner of channels, including 'free trade', missionary work, education and charity work.

What follows is a demonstration of how INGOs are increasingly being co-opted into the organic intellectual strata of North American society to remake the African lifeworld ${ }^{3}$ in the image of the West.

\section{From 'Rebels' to 'Hegemons', resistance to incorporation}

It is pertinent to examine some of the good work of INGOs in Africa. International NGOs have offered and continue to offer important, even vital, 
services in Africa. As Johnstone and McGann (2006:1) rightly note, INGOs have been a positive force in international affairs, working to alleviate poverty, protect human rights, and provide relief worldwide. Johnstone and McGann further note that:

[INGOs] such as Amnesty International, Greenpeace, and the International Campaign to Ban Landmines have helped bring non-governmental organizations the international recognition that has made 'NGO' a household word. Some NGOs gained notoriety by organizing large-scale protests that captured international headlines due to the violence and disruption they caused. Still others have organized meetings to coincide with the official gatherings of the G-8, the World Trade Organization, the World Bank, and the International Monetary Fund with the intent of challenging their legitimacy.

They add:

Milestones in this largely non-violent [I]NGO revolution ... include the influence of environmental activists on the outcome of the 1992 Earth Summit in Rio de Janeiro; the international coalition of groups led by the South Council that developed the 1994 'Fifty Years is Enough' campaign directed at the World Bank and International Monetary Fund; and the labor, anti-globalization, and environmental groups that derailed the 1999 Seattle WTO meeting. The effectiveness of these efforts stunned the major multilateral institutions and governments worldwide and forced them to develop ways to engage and involve NGOs in their deliberations and decision making. With their place in world politics now firmly established, the majority of NGOs have moved from protesting on the streets to contributing to policymaking in the boardrooms of the United Nations, World Bank, World Trade Organization, and the International Monetary Fund.

INGOs provide an essential lifeline to many millions of people in Africa and other parts of the world. Thanks to the good works of many INGOs thousands of African lives have been saved, the eyesight and limbs of countless numbers of impoverished Africans have been restored, and wildlife in countries such as Kenya, Tanzania and Uganda has been preserved. Many INGOs are in the forefront of the fight to protect and advance human rights in Africa's fledgling democracies. INGOs are the rapid-response unit to humanitarian disasters all over Africa. The foot soldiers of INGOs often risk their lives lending a hand in 'hotspots' and volatile areas during conflicts, and providing unconditional services to poverty-stricken people. In many cases, INGOs are the first to step in to save lives as governments and the United Nations dither and quibble over the pros and cons of moving into troubled 
areas. In concrete terms, INGOs saved over twelve million Ethiopians from starvation and death in the 1980s and they are saving the lives of millions of displaced Sudanese in the Darfur region in 2006 (Johnstone and McGann 2006).

According to Bofelo (2005:1) civil society organisations (CSOs) are a double-edged sword; they can be both agents of change and servants of the status of quo. CSOs have 'the potential of becoming organs of workingclass, power-facilitating, bottom-up, grassroots-oriented and participatory democracy by appealing to the under-classes spaces, platform, strategies, skills, and expertise ... through which they can challenge the establishment, place demands on power and contest its hegemony'. In addition, Bolefo (2005:1) insists, CSOs 'could also be an effective media of [sic] imparting alternative information, knowledge and education that challenges the information, knowledge and education transmitted by mainstream educational institutions and the corporate media to entrench the philosophy, culture, ethics, mores and values of the dominant/ruling class so as to conserve the status quo'. But CSOs 'can also serve to legitimatize the powers that be and preserve the status quo by restricting people to a reformist agenda geared only at searching for solutions within the confines of the prevailing system instead of exploring possibilities of transforming, reconstructing and overhauling the system' (p.2).

Bofelo (2005:2) explains that, 'by virtue of their involvement in advocacy, lobbying and interventions NGOs, are an integral part of social institutions and agencies contributing to the process of education and socialization which is the re-establishment and re-enforcement of the prevailing and dominant norms-and-value system in a society'. Bofelo concludes that CSOs can either legitimise the existing socioeconomic and political system and maintain the status quo 'or [question] the current dispensation and [offer] alternative ways of conceptualizing social reality and organizing society for the collective good of all of humanity and the preservation of the entire earth' (p.2).

Like most social movements, many of today's best-known international NGOs are metamorphosing from protest and counter-hegemonic groups into mainstream organisations. As they become more settled they blend into the mainstream, selling out - mutating from watchdogs to lapdogs. Many NGOs have embraced a version of corporatism and an affinity with the Western governments and big corporations, whose 'neoliberal trade policies remain a source of much of the world's poverty' (Bond, Brutus and Setshedi 2004). Faroohar (2005) notes that NGOs are also dropping their image as anti-capitalist do-gooders and adopting the look of the Fortune 500 companies that they have been known to criticise.

Yesteryear activist or radical NGOs have now become 'Coopted NGOs' or 'CoNGOs', sucked into the establishment either by design or the exigen- 
cies of the times. Commenting on the CoNGOs, James Petras and Henry Veltmayer ${ }^{4}$ (2001:2) note that International CoNGOs 'confer with top business and financial directors and make policy decisions that affect - in the great majority of cases, adversely - millions of people, especially the poor, women and informal sector workers'.

The process of hegemony is aided tremendously by INGOs acting as 'organic intellectuals', using their organisational and rhetorical skills to design micro-projects and craft populist language aimed at stopgap solutions, which in fact promote and serve the local and global status quo.

\section{NGOs as organic intellectuals}

Gramsci (1971:7-14) divided intellectuals into two main categories: traditional and organic intellectuals. The former include priests, lawyers, notaries, teachers and doctors (p.14) and seem to represent 'an historical continuity uninterrupted even by the most complicated and radical changes in political and social forms' (p.7). While these traditional intellectuals 'put themselves forward as autonomous and independent of the dominant social group' (Ibid), they are intellectuals of the ruling class, whose intellectual status and power are so great that they constitute an elite, able to assume the mantle of permanence and claim insight into eternal truths. The latter are called organic intellectuals because they perform an educational and organisational role on behalf of their class, giving it 'homogeneity and an awareness of its own function not only in the economic but also in the social and political fields' (Ibid). These organic intellectuals are distinguished less by their profession, which may be any job characteristic of their class, than by their function in directing the ideas and aspirations of the class to which they organically belong. Anyone considered an organic intellectual must be involved in active participation in practical life, as constructor, organiser, 'permanent persuader' and not just a simple orator (p. 10).

Mayo (1999:127) proposes that organic intellectuals have a conscious alignment with a particular political movement. They can be one of three types: first, they can be organic to the dominant class or group, which means they serve to mediate the ideological and political unity of the existing hegemony (p. 41). Such organic intellectuals are thinking and organising functionaries of a dominant class attempting to maintain its hegemony (p. 85). For example, the organic intellectuals of transnational capital constantly struggle to change minds and expand markets (p. 132). Second, organic intellectuals can be organic to a subordinated class or group aspiring to power, engaging in the war of position that enables it to secure the alliance(s) necessary to succeed (p. 41). While striving to create an alternative hegemony (p. 
85), these intellectuals have a conscious commitment to the class that undertakes the task of transforming society (p. 127). Third, they can be organic to a subaltern group, which means they contribute to an intellectual and moral reform to lay the foundations for a socially more just society (CASAE, 2005).

Petras and Veltmayer (2001:3-7) note that NGOs from both northern and southern hemispheres 'deflect popular discontent away from the powerful institutions towards local micro-projects, apolitical "grass roots" self-exploitation and "popular education" that avoids class analysis of imperialism and capitalism' (p. 3). Petras and Veltmayer further observe that on the one hand, NGOs 'criticize dictatorships and human rights violations but on the other they compete with radical socio-political movements in an attempt to channel popular movements into collaborative relations with dominant neoliberal elites' (ibid.).

Petras and Veltmayer (2001) insist that in reality, non-governmental organisations are not non-governmental, since some receive government funds or work as private subcontractors for governments. 'Frequently they openly collaborate with governmental agencies at home or overseas' (p. 7). Many North American NGOs receive funds or subsidies from the American and Canadian government. Some are directly subcontracted by government departments such as the Canadian International Development Agency (CIDA) and the United States Agency for International Development (USAID). According to the observations of John Elkington (2006) the international NGO sector is approaching a turnover of $\$ 1$ trillion a year, and therefore could join the ranks of the most influential institutions of the twenty-first century. Many leaders in the field, according to Gavin Power (2006), are 'moving beyond a culture of criticism to one of engagement with business and/or other partners in a search for solutions' (7).

Johnstone and McGann (2006:5) highlight the cooptation of NGOs by the World Bank, observing that more than half of World Bank projects are currently executed in cooperation with NGOs. "This ... not only "co-opted" some of the Bank's former critics but also created a situation in which "NGOs" are at the center of the World Bank policy, and moreover determine them.' Bob (2005) sees an unholy alliance between the emerging partnerships in international development aid delivery. Bob notes that the criteria used to determine which crisis to attend to is based not on a 'meritocracy of suffering' but on the priorities determine by the development partners that deliver the aid. Those on the receiving end are excluded when priorities are determined. Bob writes: 'But even a cursory survey reveals that many of the world's worst crises remain off the international agenda' (p.1). Thus, for example, the civil and interstate conflicts in the Democratic Republic of 
Congo since the mid-1990s, dubbed Africa's 'first world war' and which claimed over four million lives, 'scarcely registered overseas'.

The hegemonic position of Canada and the United United States in Africa is silent, non-threatening and imposed without force. Canadian and American agencies simply dictate the terms of interaction to their advantage. The process begins at the local community level in Canada and the States. Ordinary people are exposed to thousands of visual and audio images, via the mass media and which denigrate 'inferiorise' African cultures through 'development pornography' couched as compassion-eliciting media campaigns.

In an article titled 'Not enough flies to create the right effect', Sankore (2006) observes that for years, development and aid charities in the West have adopted a 'shock and astonish' strategy in soliciting donations. 'They believed the best way to raise funds is to shock people with astonishing pictures of poverty and disease from the “developing' world” (p. 3). As Sankore (2006:36-37) further notes:

The Make Poverty History campaign, Millennium Development Goals and the Commission for Africa have again focused attention on existing poverty in Africa, Asia and Latin America. New targets have been set just as in the 1970s and 80s when the target to end world poverty was the year 2000. New targets mean new campaigns and the type of images to draw attention to the famine in Ethiopia in 1984 and ' 85 will need to be updated. Unlike the past, however, there are now even more development charities competing for a limited 'market' of givers.

The implications are clear: 'Each image depicting poverty and disease needs to be more graphic than the next to elicit more response' (p. 36). Local communities in Canada and the United States respond to these campaigns by creating even more agencies to address humanitarian needs in Africa. The creation of more aid and development agencies leads to frenzied activity among NGOs, who vie to be the best in penetrating the hearts of potential givers. Such competition engenders the production of even more powerful 'development pornography' (p. 37).

Not surprisingly, INGOs have mushroomed across North America and indeed across the globe. In the United States alone, there are 1.5 million nonprofit organisations and their budgets reportedly reached billions of US dollars. The 160 INGOs associated with InterAction have a combined annual revenue of $\$ 2.3$ billion, almost half of which comes from private donations (Johnstone and McGann 2006). The number of INGOs rose from 6,000 in 1990 to 26,000 in 1996 (The Economist 2006.) According to the United Nations Development Programme (UNDP) Report, nearly one-fifth of the world's 37,000 INGOs were formed in the 1990s. 
More than 1,500 INGOs are registered observers of the United Nations. The number of INGO branches in Africa rose 31 percent to 39,729 between 1993 and 2003. The rate of increase in Africa was higher, at 40 percent. The number of INGOs and NGOs with strong international links headquartered in Africa rose by 33 percent to 867 in the same period. The not-for-profit sector is now valued at over $\$ 1$ trillion a year globally (Maclean 2005).

NGOs in Africa manage nearly \$3.5 billion in external aid. Nicholas Stockton (in Faroohar 2005), a former executive director and 20-year veteran of Oxfam, was quoted as saying, 'There's a market for good works, and it's big business'. Faroohar (2005) reports that NGOs grew faster than the rest of the US economy, even during the late 1990s. US NGOs' expenditures grew 77 percent faster than the American economy as a whole between 1977 and 1999 (p. 10).

\section{Rewards}

Donors, both individual and corporate receive generous rewards for their contributions in the form of tax deductions, community recognition and development fund awards. Canadian and American NGOs themselves reap benefits in the form of substantial salaries, paid vacations, and other perks.

According to an Actionaid International report, nearly $\$ 20$ billion, or more than a quarter of annual development aid, is spent by donor countries to fund 'sometimes dubious and excessive technical assistance' - a term used to refer to research, training, and consulting services (Nduru 2006:1). Nduru reports that based on 2004 data, it costs about 20,000 dollars a year to keep an expatriate consultant on staff. School fees and child allowances account for more than a third of this expense, which could be reduced with greater use of local advisors. 'money is being spent on consultants who are earning up to 1,000 dollars a day', Caroline Sande Mukulira, South Africa country director for ActionAid International, told IPS' (p. 1).

The Actionaid International report is as revealing as it is disturbing. It notes: 'perhaps more alarmingly, however, these high-priced advisors may fail to deliver lasting benefits'. Furthermore, technical assistance is often far less neutral than the term would imply. The donors use technical assistance 'to police and direct the policy agendas of developing country governments, or to create ownership of the kinds of reforms donors deem suitable' (Nduru 2006:1). Donor-funded advisors have even been brought in to draft supposedly 'country-owned' poverty reduction strategies.

Technical assistance that is too expensive, or ineffective, amounts to 'phantom aid' as opposed to the real aid. Actionaid also identified other trends that turn real aid into phantom aid, including counting debt cancellation as aid, 
requiring aid to be spent on goods and services from donor countries irrespective of whether these offer the best value for money, and coordinating donor aid poorly. Actionaid estimates nearly half of all aid to be phantom aid (p. 3).

'Real Aid 2' states that the inefficiency of technical assistance is 'an open secret within the development community'. According to the management consultancy McKinsey \& Company, the US non-profit sector alone could free up at least $\$ 100$ billion in additional value by changing its notions of stewardship and its operating practices (Bradley, Jansen and Silverman 2003).

NGOs have become the latest vehicle for social upward mobility for the ambitious educated classes. Academics, journalists and professionals have abandoned their earlier interests in poorly rewarded leftist movements for lucrative careers in managing NGOs (Petras and Veltmayer 2001). The CEO of the American Red Cross took a severance pay of over \$1 million. The CEO of the Wildlife Conservation Society receives an annual salary of over half a million dollars (American Institute of Philanthropy 2006). Faroohar (2005) reports that salaries at non-profits are rising as recruits arrive from the corporate world. Marsha J. Evans, president and CEO of the American Red Cross, manages a \$3 billion budget, and makes $\$ 450,000$ a year.

\section{The good becomes the bad: Unintended consequences of the good works and development pornography}

The road to hell is often said to be paved with good intentions. The converse of this saying is equally true: the road to heaven may be strewn with ill intentions. The law of unintended consequences manifests itself very potently in the activities of NGOs in Africa. Graphic and manifest depictions of poverty, projected on a mass scale by an increasing number of organisations over a long period of time, cannot but have an impact on the consciousness of the target audience. That is the desired objective (the good intentions) of the 'development pornography' campaign engaged in by North American NGOs. But there can also be unintended consequences (Sankore 2006:2). The subliminal - unintended - consequence of 'development pornography' reduces Africans to perpetual, insatiable beggars who require inordinate and increasing amounts of Western help. The implicit message of 'development pornography' is that without Western aid charities and donor support, Africans will soon be extinct from starvation and disease. Such truncated and simplistic messages reinforce and entrench existing anti-African stereotypes, strip Africans of their dignity and humanity, and spawn racial prejudice. As noted above, various means of communication are used to portray and perpetuate the anti-African stereotypes. The intentions may be good, but the 
consequences certainly are not. While authors of these images may, on the surface, mean well, they do maximum damage to Africans everywhere.

An African living in the United States, after attending a video presentation by an American who had just returned from the African's home town, recounted her reaction: 'The show was filled with stereotypical photographs of poor children' (Kiem 1999:63). She was so upset by the distorted presentation that she was unable to talk to people after the show. Such images are, of course, ubiquitous in 'development pornography'.

Canada and USA have enacted strict laws to protect the identity of their own children in the media. However, in 'development pornography' the images and identities of African children are fair game; their naked bodies, their faces, their identities are often exposed to the full glare of the world. In their push to raise charity funds aid organisations throw caution to the wind; they exploit the images of African children in distress in countless television commercials, infomercials and films. The children are often cast as passive and helpless, with little or no support from their own society. These images saturate Canadian and US television on a daily basis. Visuals of poor, unfortunate, scantily clad, sickly children are the stock-in-trade of aid agencies as they 'sell' compassion to Canadians and Americans at HIV/AIDS and famine exhibitions, in order to gain maximum donor response.

\section{African immigrants and development tourism}

The North American laws that promote equality, diversity, multiculturalism are also largely ignored when agencies are at work in Africa. The official adoption of multicultural policies in North America has created societies in which citizens have gradually learned to co-exist, at least superficially, in racially and ethnically diverse environments. Increasing numbers of Canadians and Americans have become more sensitive and considerate towards the 'racial other'.

Despite these changes, Africans living in Canada and the USA are seldom employed by development agencies to do work in Africa. An African immigrant turned Canadian citizen, who formerly was her native country's ambassador in Europe, was told that she could not do volunteer work for a Canadian aid agency in Africa because the positions were 'reserved for native born Canadians only' (Van Wyk 2006). But these immigrants are in fact better qualified to do such work, many speaking more than one African language in addition to English and/or French, the two official languages in Canada and in most African countries. Many are trained to work in the agencies' operation fields, or have relevant work experience, and needless to say are familiar with African culture. It would seem logical that aid agencies in 
Canada and the USA would value Africans who have the advantage of both 'insider' and 'outsider' perspectives. The unwillingness of Canadian NGOs to employ Africans may stem from an unspoken commitment to create jobs for native-born Canadians and Americans in order to promote their own values - thereby perpetuating Western global hegemony.

A visit to any African country by native-born Canadians and Americans will reveal the following scenario. Villagers living with no infrastructure who walk miles to the market, while shiny new NGO Land Rovers and SUVs tear down the highways, forcing the local population to jump out of the way. Local restaurants crammed with boorish groups of foreign workers who loudly order their meals and beer while the local staff rushes to accommodate them. As villagers return from market to homes with no electricity, foreign workers retire to gated compounds and enjoy television. As Munene (2005) writes, 'The people that work for the agencies in Africa enjoy the great tourist attractions of Africa and live in the wealthy suburbs of African cities that are never shown to the donors'.

Many donors become so motivated that they become development tourists themselves, visiting Africa and bringing back 'development pornography' for fundraising purposes. The most common form of development tourism consists of short urban-safari based holidays, which include a brief rural visit to capture some of the images of countryside poverty without any understanding of its nature. Some short visits include minor tasks such as handing out gifts, medicine or other goods. These tasks take place with little or no knowledge of the traditional lifeworlds of Africans. When development tourists return to North America they are considered experts on African development, lecture at universities and colleges, receive awards, and raise more funds to repeat their safari tourism.

Academic-oriented tourists who take short urban-safari holidays in Africa conduct a few short interviews which they use to write up some extensive research reports. Such academic development tourism is very often costly, and most such large-scale surveys are monumentally inefficient both in the data quality and the long delays in analysis and reporting of the data. Furthermore, it is very unlikely that any of these North Americans speak one or more of the over 2000 languages in Africa, or conduct their interviews in an African language.

An extreme form of development tourism involves mobilising large groups of Canadians and Americans to go to Africa for a specific task. In one instance, a large group of American builders went to the Congo to build schools in five villages. The villagers used the classrooms but did not maintain them because of the ongoing war in the Congo. Many villagers had to leave tem- 
porarily to avoid the war. The buildings fell into disrepair, and a subsequent request to America to assist with the repair went unanswered because American organisations had moved to other projects on safer ground (Keim 1999:79).

Other large groups of Canadians and Americans go to Africa to plant gardens and build orphanages (Phillips 2005:1). The garden planting tour includes a safari and sightseeing. While this development tourism is good for the African tourism industry, the majority of the money intended as aid relief is spent on airfares and unsustainable gardening projects. These development tourists enjoy stays in luxurious African holiday resorts, but bring back images of poverty. Thus, many of the activities of development tourists reinforce negative stereotypes and misconceptions about Africa.

\section{The role of international NGOs in channelling emotions}

Mazzena (2006) draws our attention to the role of INGOs to legitimise specific interpretations of the African reality and, to channel the public's emotions. Mazzena contends that INGOs, are complicit in portraying Africans as incapable of going it alone in times of trouble, and as mere passive receptors of outside aid. 'These representations in turn, enhance the prestige of those who help the "victims" and make the providers' action more acknowledged, all of which has a great impact on the fund-raising plans' (p. 5).

Ronning (1998) points to the existence of a 'structural synergy' between international NGOs, the occurrence of catastrophes, and the international media in the various forms of so-called 'disaster reporting'. True, some international NGOs, including Oxfam, Save the Children and EveryChild, launched a campaign in the 1980s on the 'ethical use' of images of Africans. However, the continued use of 'development pornography' to solicit aid for Africa is an indication that the campaign failed to have the needed impact. International NGOs also form an unholy alliance with the international media in employing what Susan Moeller (1998:20) calls 'compassion usury' - inundation of collective emotionalism - to mobilise the public's conscience and support. For instance, in emergencies and crises this usury is fueled by the non-stop broadcasting of negative images by humanitarian organisations and media operators, showing the plight of the victims. This situation is further complicated by the fact that simultaneous events 'vie' for visibility, which results in the public being sensitised 'for only one crisis at a time'.

Sponsors of all sorts (international organisations, major powers, NGOs), as well as the media regard Africa as the continent of poverty par excellence; Africa is synonymous with poverty (Amselle 2006). The images of Africa constructed by the mass media in the minds of Westerners in general, and 
Canadians and Americans in particular, have congealed into die-hard stereotypes that are damaging not only to Africans but also to Westerners.

The image in the collective mind of North Americans is that of a societyless Africa bereft of universities, factories, cities, research centres, communications, intellectuals, skilled workers and craftsmen. Honoré (2006:1) dentified two elements in this one-dimensional image: 'an unbroken chain of natural and social catastrophes, on the one hand, and the multicolour "beadstring” of tourist exoticism'. According to Amselle (2006), the continent is perceived as an 'underdeveloped landmass' afflicted by a host of ills, ranging from environmental and climatic vicissitudes to diseases, famine and civil wars. Amselle notes: 'The verdict is clear. Africa is a cursed continent and its curse is the result of the biblical exigencies which, ever since the fourth century, have been considering black Africans as descendants of the Old Testament Ham. And this pattern is still at the root of the Western perception of Africa that confines the continent within the boundaries of a vicious cycle of poverty-corruption-disease-tribal wars' (p. 3).

A disturbingly large number of Americans and Canadians still look at Africa through categories such as 'savage', 'tribe' and 'primitive'. They believe in the dogma that civilisation is a gift from North American to Africans, and that Africans have contributed nothing to the global stock of knowledge or civilisation. Accepting the Western hegemonic fiction that Africans are inherently inferior, many Westerners, including those who direct or work in NGOs, are sceptical, to say the least, of the great contributions of Africans to world civilisation. They instead remain silent over the persistent atrocities and crimes against Africans by the Trilogy of Slavery, Colonialism and Neo-colonialism (TESCN), euphemistically called 'globalisation', and routinely excuse these crimes and atrocities when they cannot deny them or wrap them in silence. Faced with what some scholars call the 'Black Holocaust', the majority of Euro-Americans blame Africans for what happened to them, and reject their 'overall responsibility for a process they initiated and still control' (Amsell 2006:2). They morally cancel out the violence exacted on Africans through TESCN with the counter-violence of the Africans who seek to liberate themselves from Euro-American domination.

In terms of their cognitive abilities, Africans are perceived as unable to plan or care for themselves, constantly and inevitably primitive, irrational, superstitious, lazy, and barely managing to survive. 'When these characteristics are transferred to know-how and professionalism', Mezzana (2006) points out, 'the result is a picture of individuals and groups possessing poor cognitive and operative capacity, ill suited to managerial positions and depending on outside aid for any emergency' (p. 5). 
On the political level the current stereotype is one of anarchic tribalism which has ignited and continues to set ablaze multiple 'tribal' and ethnic wars across the continent. These conflicts are believed to be driven by blind and irrational forces instead of nationalistic tensions or ideological differences. The continent is also perceived as dotted by a host of despotic and corrupt leaders. The tacit conclusion is that nothing can work in Africa and no form of government, democratic or otherwise, is possible. The image is of a continent in perpetual crisis, developmentally hopeless without palliative and charitable aid provided and managed by good-willed (non-African) actors.

\section{Anti-African stereotypes, myths and misconceptions}

The roots of these myths, misconceptions about Africa and Africans are traceable to the North American ethos, political culture and education. The North American mindset about Africans and their continent was conditioned over the centuries with the help of a vast repository of the findings, models and literature in social science. This stock of knowledge has been passed off as universal, neutral and objective. However, as Wiarda (1984) points out, in such a repository the vast bulk of this accumulated knowledge is in fact biased, ethnocentric, and not universal at all. They are based on the narrow and rather particular experiences of Euro-American culture and may have little or no relevance to the rest of the world. Tied to this form of ethnocentrism is social evolutionism. Race logic in America and Europe, which preceded Darwin's evolutionary theory was built on the notion that if humans had evolved, presumably from apes, some humans had evolved more than others. It was presumed that the 'white' race - especially upper- and uppermiddle-class white males - is furthest along the evolutionary line.

In the evolutionist eye Africans were less evolved. As Keim (1999:159) notes, Africans were seen as 'living ancestors', present and yet representative of another time. Alternatively, they were 'perpetual children, not yet adults and therefore only marginally significant in contemporary time'. Keim further notes:

In the nineteenth century, the root cause of African backwardness was considered to be their race. Most whites, for example, believed that Africans lacked philosophy because they lacked the biological capacity to produce philosophy. Over time - a very long time - blacks would evolve the ability to philosophize like whites, to create real art and to rule themselves, but until that moment, the best that could be done was for white men to accept the burden of control and care as one might do for children. In practice, of course, the White Man's Burden of taking care of Africans turned into the Black Man's Burden of suffering exploitation. 
Because Africans were presumed to represent a more primitive time, most Westerners, including most Americans, could easily accept African subjugation and overlook African contributions to history (p. 159).

Perhaps the most powerful medium, beside the mass media, through which anti-African stereotypes and myths and misconceptions have been transmitted, is the school. The North American educational system is based almost exclusively on traditions, which treat other cultures and histories as at best peripheral and at worst inferior. The education system is essentially rooted in the Greco-Roman and Judeo-Christian traditions and European history, from which derive a set of concepts, ethics, and governing norms and experiences.

North American concepts of justice, fair play, good government, progress, and development are all based on, and reconstructions of, the mechanical, unilinear dichotomies postulated by social scientists and ideological stalwarts that include Kant, Hegel, Durkheim, Marx, and Weber. Underlying these North American reconstructions is the assumption that North America is the exemplar of humanity and progress, the rest of the world should inevitably follow the same developmental path as North Americans. These assumptions, concepts, and ideologies have worked their way into the collective consciousness of many Canadians and Americans (Brooks 2004). Some have crystallised into myths, misconception, stereotypes and prejudices about non-Westerners, including Africans.

Research conducted by the authors in Canada and the USA between 1999 and 2004 revealed lingering misconceptions as well as dangerous myths and stereotypes in the minds of a disturbingly large numbers of Canadians and Americans (Quist-Adade 2005; Van Wyk 2006). The overwhelming impression gained by studying Canadian and American attitudes, perception and language about African people seems to be that African people are 'backward' and 'need help'. Among other things, the majority of those interviewed did not think Africans could take care of their own development needs. Some offered solutions that revealed a superiority complex. For instance, one interviewee remarked: 'They [Africans] need to become like us'. Some were less overt, choosing instead more 'diplomatic' language.

However, even such diplomatic language could not belie the subliminal racism and paternalism of the respondents. Many of the respondents strove to be positive in their attitude towards Africans but still could not resist the temptation of being condescending. For example, one respondent, after referring to Africans as 'innocent victims who we should understand and empathise with', went on to suggest that 'they should have less children, since the source of poverty in Africa is too many mouths to feed' (Quist- 
Adade 2005). They try to be positive by referring to African people as 'innocent creatures' or 'childlike'. Others are not so polite. Instead, they adopt overtly racist tones; they describe African people as 'primitive', 'savage', 'tribal', or 'cannibals'. For example, former Toronto Mayor Mel Lastman, used Toronto's multicultural diversity to bolster the city’s Olympic bid, and he then turned around and stated that he was afraid of going to Mombasa, Kenya, because he feared of being boiled in a pot by Africans while they danced around. These perceptions of African people often determine the terms of interaction of some individuals and agencies that work in Africa.

Other studies have revealed that Canadians and Americans, as indeed most Europeans, mistake the African continent for a single country. They tend to think of Africa as mainly rural, 'grand landscapes filled with fascinating walks, [and] fearsome animals’ (Kenyon 2005). They perceive the continent as a site of major natural catastrophes (floods, volcanic eruptions, droughts, etc.) and brutal social conflicts, but also as a breathtakingly beautiful wild habitat. Thus, in North Americans' eyes Africa is rife with danger (Hawk 1992), yet simultaneously an exotic continent, the land of adventure.

Some think the continent consists mostly of vast stretches of dry desert, while the Sahara Desert actually covers approximately one third of the continent. Others believe that Africa is all jungle or rainforest, when in reality only a small percentage of the continent, along the Guinea Coast and in the Zaire River Basin, is rainforest.

Absent from the collective mindset of Canadians and Americans are that the fifty-three nations in Africa inhabit the second largest continent in the world; that Africa is home to more than 800 million people, is more than three times the size of the United States, and includes 20 percent of the world's total landmass.

Many of these widely held misconceptions about Africa were confirmed by an American museum survey in 1999 (Keim 1999:4). The authors of the present paper replicated the same survey in 2005 in Canada and found remarkable similarities. Historical misperceptions, ignorance, stereotypes and myths about Africa permeate the views of ordinary Canadians and Americans. Respondents believed Africa to be a primitive place full of wild animals and people that need help; they regarded Africans as primitive, savage, tribal cannibals.

\section{What is the problem?}

It also became apparent from our survey of NGO activities in North America that Canadian and American aid agencies do not appear to pay adequate attention to the fact that the meanings Africans attach to their lifeworlds are 
an essential part of aid delivery and development. They also fail to appreciate that development is a continuous process that cannot be fully understood, explained or controlled by outsiders. Instead, they aid in dumping westerncrafted projects and 'solutions' on African societies under the guise of humanitarian assistance. North American aid agencies, by and large, have only succeeded in helping to maintain the global status quo of western hegemonic domination and African dependence by delivering conditional aid.

It is dehumanising to set conditions and apply policies in which people are required to convert or transform their lifeworlds in order to receive humanitarian aid. Claude Ake (1996:118-119) described such policies as 'grim notions that can only be inflicted by people who do not belong to the adjusting society'. African people are bombarded with messages that suggest lifestyle conversions, transformations and alternatives. Canadians and Americans blame African culture and lifestyle for the 'failure to become like us'. The transfer of resources to help the 'inferior African' to 'become like us' or to 'catch up' is perceived by some as the solution for African development needs. Another perceived solution is empowerment. Empowerment was described by one of our survey respondents as: 'Empowerment means we [Canadians and Americans] have the knowledge and the skills to teach them [Africans] the "know how" (van Wyk 2006). These preconceived ideas contribute towards façades of participation. Agencies proudly emphasise that they are working with local organisations and individuals in Africa. However, they never reveal that the participation of African organisations and individuals is restricted, confined to a few selective organisations or individuals that adhere to certain preconditions. This participation façade is often used to create credibility or please big donors.

This is so tragic, because when international NGOs perpetuate these convenient myths, they become part of the long-term problem even while providing short-term, band aid solutions. They have bought into the myths and act in concert with self-fulfilling prophecies, they create stereotypical images of Africa - the continent of the poverty stricken, both in terms of resources and ideas. 'Year upon year, they keep on producing even more pornographic images of poverty in Africa in order to raise money to save a life today and lose even more tomorrow' (Ibid).

This is not to suggest that all types of aid are inimical to Africa, or that the work of INGOs in the areas of HIV/AIDS treatment and prevention or malaria research, for instance should stop. We support the statement of ObengDiawuoh (2006) that we should avoid generalisations about the performance and integrity of the numerous NGOs operating across Africa. We need to refrain from a blanket indictment or adulation of 'all' NGOs. Some NGOs 
perform essential tasks after wars such as clearing the minefields in countries where governments are overwhelmed with other after war responsibilities (Jez 2006). 'It is not fair to discredit the entire organization's operations of all INGOs in African countries because of a few bad apples' (Qaal 2006). The president of Ghana's International Council on Social Welfare Mr Charles Abbey, stated that it is not fair for society to blacklist the entire NGO body because of a 'few bad nuts' (Adjei 2006). Some of the staff working for NGOs risks their lives (Maseko 2006). Since the middle of 2005 mobile teams from Doctors Without Borders provided medical care and emergency surgery in the Democratic Republic of Congo (DRC), the Central African Republic, Chad, and Sudan. These doctors are not only dealing with war casualties but with health care emergencies where the war wiped out all the local health care facilities (Collins 2006). Their work in Niger and Sudan and Darfur, include the treatment of bacterial meningitis, measles, acute malnutrition and cholera (Defourny and Blanty 2006). There are some NGOs and individuals working for NGOs in Darfur region in Sudan that make remarkable contributions to the lives of displaced people. We recognise the important work of NGOs and we are acutely aware that there are no short cuts to economic growth and prosperity, that African development requires good governance (which is lacking in many African countries) judicious use of resources, the promotion of local talent and hard work.

When all is said and done, development programmes in Africa require more than aid; people involved in these programmes must arm themselves with a deeper knowledge of the historical and structural bases of the continent, and sensitivity to African sensibilities, cultural norms and life-styles. Canadian and American NGOs need to review questions such as: Why is Africa poor today? Is it poor, or in fact impoverished? What is the remedy? Do Africans need assistance? If so, what type of assistance? From whom? Under what conditions? To these key questions, Canadian and American NGOs appear not to have the right answers. From our analysis of Canadian and American NGOs' activities in Africa, we submit that these NGOs either are silent on these crucial questions or give false answers. Consequently, these organisations continue to give false diagnoses and offer false remedies.

We submit the following: First, INGOs have for far too long avoided acknowledging the linkage between the trilogy of slavery, colonialism and neo-colonialism (TESCN) and the contemporary conditions of Africa. Second, NGOs have not adequately addressed the fact that the TESCN plundered and enriched North America and continue to do so even now. Third, NGOs have not confronted in a bold and innovative manner the fact that the 
structures of international relations since the Second World War continue to facilitate the plunder of Africa by the Euro-American powers.

Many INGOs have bought into the myth crafted and peddled by the Bretton Woods Institutions - the IMF and World Bank as well as the World Trade Organisation (WTO) - that free trade is the answer to African poverty. The radical truth, however, is that African countries who swallowed the bitter IMF pill of SAP in the 1980s and 1990s saw exports boom but hunger worsen. It became apparent that export-oriented agriculture hurt the poor. Lappe and Collins (1998) have listed several ways in which exportoriented agriculture is inimical to African countries: It allows local economic elite to continue making profits without trying to raise the purchasing power of local people; it encourages local elite to produce export instead of food crops; it leads to subsistence wages and miserable working conditions due to intense competition among exporters; and it makes local staple foods scarcer and therefore costlier.

Another myth into which INGOs have bought is that more aid from the 'Global North' will help African countries. Here again, Lappe and Collins (1998) argue that aid policies of most of the Northern countries often actually make it harder for people to feed themselves. Citing the US, Lappe and Collins say that several things are wrong with international aid as it is currently conceived, crafted and implemented. First, US assistance is highly concentrated on very few governments. Second, US food aid is not related to need, but to bolstering friendly governments. Third, US aid is concentrated on governments dead-set against reforms in favour of the poor. Fourth, the US cuts off aid as a form of punishment. Fifth, the biggest form of US aid is military help to arm governments against their hungry people. Sixth, most development aid fails to help the poor and the hungry. As Lappe and Collins assert, the way people think about hunger is the greatest obstacle to ending it. And they exhort policy-makers to first change the way they think about hunger before they can even begin to end it. Concluding, Lappe and Collins (1998) point out, '[I]t is obvious, listening to our policy-makers, that their idea of poverty and hunger is laced with many of these myths. It is why the pro-poor rhetoric is seldom matched by genuine pro-poor action' (p. 12). This is equally true of INGOs.

\section{Reassessment justice, not charity: The need for a new paradigm for African development}

A reassessment of the real cost to the 'beneficiaries' of charitable agencies is long overdue. As Professor Jacob Songsore, head of the Department of Geography and Resource Development at the University of Ghana, has rightly 
noted about Ghana, that country's frustration in the desire to attain a middleincome status has been blamed on the nation's inability to transform its inherited colonial economic structure (GNA, 12 July 2006:1). Songsore observes that after several decades of structural adjustment programmes, all 33 African countries, including Ghana, that had been touted by the West as high performers were mired in debt and poverty, adding that almost all these countries are those who have had to shift to Highly Impoverished Country (HIPC) status. These countries, he observes, are implementing the same poverty reduction strategy papers, this time as a condition for further donor assistance. '[W]hat we perceive as poverty today is the result of overlays of conscious policies pursued over a long historical period by the state in support of specific interests groups' (Ibid).

Any attempt to address the continent's current problems must be informed by a deep understanding of its historical past. Ignorance of the history of Africa's socio-cultural and political development has impoverished international NGOs' understanding of the continent and contributed to a distorted view of the problems facing Africa today. The detachment from history that characterises contemporary research and humanitarian work in Africa is explained by unquestioning acceptance of Western hegemonic views. According to this perspective, Africa's current crises are rooted in poor management, corrupt and dictatorial leadership, closed markets, and lack of Western-style democracy. Thus, once these 'root' problems are solved, Africa will be on the road to economic development. But this view is ahistorical, universalistic and reductionist. It also deflects responsibility for Africa's recurrent crises away from Western governments and blames the African victims.

Africa is a victim of historical tragedies - the trilogy of slavery, colonialism and neo-colonialism (TSCN). One wonders if it would be asking the impossible to call on INGOs in Canada and the USA to remove the coating of moralism and sentimentality from these historical phenomena. Once this is done, to paraphrase an African journalist, they shall see slavery as the equivalent of removing all the scientists, engineers and computer programmers from a modern industrial economy such as the USA. How many hours would the US economy last without its scientists, computer programmers and engineers? Yet, this is the parallel of what happened to Africa when slavery robbed her labour-intensive, subsistence agricultural economy of its most productive women and men for four centuries (Adjei 2006). Without this historical parallel it is easy for the average Canadian or American to be taken in by racist theories, which tend to dismiss Africans as genetically and intellectually inferior, incompetent, and lazy. 
Of course, Africans themselves have contributed to the creation of many of these problems, and have added to or even compounded them through the excesses of their leaders. African journalists and scholars have made no bones about these excesses, or about poor governance. One does not expect international NGOs to become public relations officers for the continent, extolling its virtues. But we expect from these NGOs a more careful analysis of events and issues, acknowledging progress as well as retrogression, success and failure.

In eliciting compassion for Africa's impoverished and advocating on behalf of Africans, aid agencies must be careful not to sacrifice the fundamental right of African people to live in a world that is meaningful to them. Agencies' operations must be geared towards the expectations, hopes and aspirations of African people and not tied to the conditionalities and demands of donor countries. For aid to be meaningful and long-lasting, it must be responsive to needs determined by African people themselves and not by outsiders. It is therefore crucial that NGOs tap into the skills and expertise of Africans living in North America. These individuals can provide vital links between NGOs and local communities in Africa. Their 'native' knowledge of the African conditions, their ability to understand local idiosyncrasies, sensibilities, customs and traditions, could prove vital to the success of projects. Their presence could also remove any sense of suspicion local communities may harbour towards aid workers from Canada and the USA.

It must be emphasised that development in Africa is not about conversion to a Western culture or a Western economic dispensation. Development in Africa is about African values. African development priorities need to be determined by African people, and to the benefit of African people. Outside aid must protect and promote African values, not destroy them.

Agency operations in Africa should begin by making sure multinational corporations, governments and INGOs are not exploitative. Conditional aid, based on pre-conditions of socio-cultural transformation, must disappear. The value of established socioeconomic and cultural patterns needs to be recognised. Agencies should focus on concrete, people-oriented objectives, and strategies that allow African people to manage their own lives.

INGOs must adopt a new orientation towards the sources of Africa's endemic and seemingly intractable problems, an orientation that aims to track the historical and structural bases of the continent's problems. Otherwise, INGOs will only be washing the outside of Africa's 'pot of problems' while leaving the inside of the pot untouched. 


\section{Conclusion}

In this article, the crucial question we have sought to address centres round how international INGOs have unwittingly become part of Africa's recurrent crises, by exporting Western-made solutions and values as part of a process of entrenching Western hegemonic control. First, we examined the history of 'development pornography' and the role Canadian and American INGOs play in constructing and reinforcing stereotypes of African inferiority, dependence and lack of development in order to conduct charity work in Africa. Second, we proposed that many North American INGOs spearhead a campaign to bring North American 'civilisation' and North American values to the 'less fortunate' people of Africa. The net result of this campaign is that NGOs work to maintain the international status quo, which is heavily skewed against Africa and other parts of the developing world, the same system they claim to be working to change. While many INGOs began their work as rebels against the 'unjust, unbalanced' global system, they sooner or later became co-opted into the 'establishment', helping to maintain and service the global hegemony of the West. Thirdly, we argued that international NGOs either ignore or refuse to take an historical and holistic approach in understanding Africa's problems, preferring instead to adopt palliative, stop-gap measures that end up deepening the continent's problems.

When considered together, these issues raise serious concerns about the wisdom of continuing to rely on the tinkering approach, the band aid, mopup approach, as international NGOs' method of choice for addressing Africa's problems.

\section{Notes}

1. 'INGOs' is used in this article to refer to the more established NGOs with global focus. The terms is used to distinguish INGOs from domestically-focused NGOs and Southern NGOs, i.e., NGOs in the so-called Third World.

2. This is the group mentioned earlier that grows organically with the ruling class, and is their thinking and organising element. For Gramsci it was important to see them for what they were: produced by the educational system to perform a function for the dominant social group in society. Burke (1999), 'Antonio Gramsci', http://www.infed.org/thinkers/et-gram.htm.

3. The term 'lifeworld' is borrowed from Habermas; it means the shared common understandings, including values, which develop over time through face to face contacts in various social groups, from families to communities. The lifeworld carries all sorts of assumptions about who we are as people and what we value about ourselves: what we believe, what shocks or offends us, what we aspire to, what we desire, what we are willing to sacrifice - and for what ends - and so forth. 
4. James Petras and Henry Veltmayer are both academics but with extensive experience in social movements.

\section{References}

Adjei, E., 2006, Ghana: NGOs Urged to Project Good Image in Society. Retrieved on October 11, 2006 from http://allafrica.com/stories/200609280553.html, Africa Events, 1998, 4. 2:54.

Ake, C., 1996, Democracy and Development in Africa, Washington DC: Brooking Institution.

American Institute of Philanthropy, 2006, Top Salaries, Retrieved on June 7, 2006, from www.charitywatch.org.

Amselle, Jean-Loup, 2002, ‘Africa’s Repulsive Charm in The Western Imagination', Les Temps Modernes, 620-621, August-November.

Bauman, Z., 1992, Intimations of Postmodernity, London: Routledge.

Blanty, S., 2006, 'The Silence Is Brutal', Retrieved on October 11, 2006 from http:/ /www.doctorswithoutborders.org/news/voices/2005/07-2005_niger.cfm.

Bob, C., 2005, The Marketing of Rebellion: Insurgents, Media, and International Activism, Cambridge: Cambridge University Press.

Bofelo, M., 2005, 'Gramsci and Biko on Hegemony and Counter-Hegemony, and the Role of Intellectuals and Mass Participation', Centre for Civil Engagement, Virginia: University of Richmond.

Boggs, C., 1976, Gramsci’s Marxism, London: Pluto Press.

Bond, P., Brutus, D and Setshedi, V., 2004, ‘Are Mainstream NGOs Failing Africa?’, ZMagazine.

Bradley, B., Jansen, P. and Silverman, L., 2003, ‘The Nonprofit Sector’s \$100 Billion Opportunity’, Harvard Business Review, May, pp. 94-103.

Brooks, S., 2004, 'Political Culture in Canada: Issues and Directions', Canadian Politics, 4(1), 70-78.

Burke, B., 1999, 'Antonio Gramsci and Informal Education', The Encyclopedia of Informal Education. Retrieved on July 26, 2006 from http://www.infed.org/ thinkers/et-gram.htm

Cahill, D., 2000, 'Neo-liberal Intellectuals as Organic Intellectuals', Retrieved on September 23, 2006 from http://apsa2000.anu.edu.au/confpapers/cahill.rtf.

Canadian Association for the Study of Adult Education (CASAE), 2005, National Conference On-Line Proceedings, University of Western Ontario in London, Ontario May 28 to May 31.

Coben, D., 1995, 'Revisiting Gramsci’, Studies in the Education of Adults, Vol. 27, No. 1, April, pp. 36-51.

Collins, S., 2006, 'Even the Sound of a Care Made People Run into the Bush', Retrieved on October 11, 2006 from http://www.doctorswithoutborders.org/ news/2006/04-14-2006.cfm

Defourny, I., 2006, Niger. We Want To Do More, Retreived on October 11, 2006 from http://www.doctorswithoutborders.org/news/2006/09-26-2006_1.cfm. 
Dyson, M., 2003, Reflecting Black: African-American Cultural Criticism, Minnesota: University of Minnesota Press.

Elkington, J., 2006, 'The 21st Century NGO: In the Market for Change’, Retrieved on July 26, 2006 from http://www.sustainability.com/insight/researcharticle.asp?id.

Faroohar, R., 2005,. Where the Money Is? New York: Global Policy Forum.

Ferguson, R., 1998, Representing Race - Ideology, Identity and the Media, Arnold: London.

Ghana News Agency (GNA), 12 July, 2006: 1.

Gidley, R., 2005, 'Rivalry Among Aid Agencies Leads Some to Development Pornography', Arizona Daily Star, 16 October.

Global Policy Forum, 2006, Global Development Policies, Retrieved July 23, 2006 from http://www.globalpolicy.org.

Gramsci, A., 1971, Selections from the Prison Notebooks, London: Lawrence and Wishart.

Hawk, B. G., 1992, Africa’s Media Image, New York: Praeger.

Honore,Y.A. (2006). 'A Viable undertaking'. African Society. Retrieved on October 1, 2006. http://www.african societies.org/n4-eng/index_eng.htm

Jez, A., 2006, 'NGOs: Achievers or deceivers?', Retrieved on October 11, 2006 from http://news.bbc.co.uk/2/hi/africa/3502733.stm.

Johnstone, M. and McGann, J., 2006, 'Power Shift and the NGOs Credibility Crisis', Retrieved on July 25 from www.globaalpolicy.org/ngoscredib/2006/01shift.htm.

Kenyon, G, 2005, 'Grand landscapes filled with fascinating walks, fearsome animals', Vancouver Sun, October 22.

Keim, C., 1999, Mistaking Africa Curiosities and Inventions of the American Mind, Colorado: Westview Press.

Lappe, F. and Collins, J., 1998, The 12 Hunger Myths, New York: Grove Press.

Maclean ,W., 2005. Foreign NGOs Map New Route to African Legitimacy. New York: Global Policy Forum.

Maseko, E. K., 2006, 'NGOs: Achievers or deceivers?', Retrieved on October 11, 2006 from http://news.bbc.co.uk/2/hi/africa/3502733.stm.

Mayo, P., 1999, Gramsci, Freire and Adult Education: Possibilities for Transformative Action, New York: Zed Books.

Mezzana, D., 2006, ‘A Cancerous Image’, African Societies, Retrieved on July 26, 2006 from http://www.africansocieties.org/n4/eng/Dossier.htm.

Moeller, S., 1998, Compassion Fatigue, New York: Routledge.

Muchie, M. and Xing, L., 2006, 'The Crisis of Hegemony and Counter-hegemony under Transnational Capitalism', Research Centre for Development and International Relations Institute for History, International and Social Studies, Aalborg University, Denmark.

Munene, H., 2005, 'Why NGO Corruption in Africa is Unsettling', The New Times, August 24. 
Nduru, M., 2006, ‘Aid for the Poor, Not for the Consultants’, InterPress Service (IPS), July 5.

Nkrumah, K., 1973, Handbook of Revolutionary Warfare, London: PANAF Books Ltd.

Obeng-Diawuoh, G., 2006, 'NGOs: Achievers or deceivers?', Retrieved on October 11, 2006 from http://news.bbc.co.uk/2/hi/africa/3502733.stm.

Petras, J. and Veltmayer, H., 2001, 'NGOs in the service of imperialism', Monthly Review, Vol. 49, 7.

Phillips, J., 2005, 'His Dream Vanished', New York: Wall Street Journal.

Power, G., 2006, 'The 21st Century NGO: In the Market for Change', Retrieved on July 26, 2006 from http://www.sustainability.com/insight/researcharticle.asp?id.

Qaal, O., 2006, 'NGOs: Achievers or deceivers?', Retrieved on October 11, 2006 from http://news.bbc.co.uk/2/hi/africa/3502733.stm.

Quist-Adade, C., 2001, In the Shadows of the Kremlin and the White House: Africa's Media Image from Communism to Post-Communism, University Press of America: Lanham.

Quist-Adade, C., 2005, 'Media Pluralism or Pluralism in the Media?’, Unpublished: Mount Pleasant, MI.

Ritzer, G., 2003, The Globalization of Nothing, Thousand Oaks: Pine Forge.

Robinson, W.I., 2005, 'Gramsci and Globalisation: From Nation-State to Transnational Hegemony', Critical Review of International Social and Political Philosophy, 8, no. 4 :1-16.

Ronning, H., 1998. An Unholy Alliance : The Relationship Between International Media and International Aid Organisations, Paper alla confereza su "Reporting Africa”, Centre for Journalism Studies, University of Cardiff (1998), Wales, 22-24 November.

Sankore, R., 2006, 'Not Enough Flies to Create the Right Effect', New African. July, 36-37.

Stockwell, J., 1984, In Search of Enemies: The CIA Story, New York: Norton Inc. The Economist, 2006, 'The Aid Industry’, March 30.

Van Wyk, A., 2006, 'Unpublished anonymous interview’, Chilliwack, British Columbia, Canada.

Wiarda, H., 1984, Ethnocentrism in Foreign Policy, Washington: American Enterprise Institute for Public Policy Research.

Wikipedia, 2006, Globalization, Retrieved September 23, 2006 from http:// en.wikipedia.org/wiki/Globalization 